\title{
PENGARUH MODEL PEMBELAJARAN TEAM GAMES TOURNAMENT (TGT) BERMEDIAKAN QUESTIONS BOX TERHADAP HASIL BELAJAR IPA
}

\author{
Azira1, Luh Pt. Putrini Mahadewi $^{2}$, I Gst. Ngurah Japa ${ }^{3}$ \\ 1,2,3 Jurusan Pendidikan Guru Sekolah Dasar, Universitas Pendidikan Ganesha \\ Singaraja, Indonesia \\ e-mail: azira@undiksha.ac.id ${ }^{1}$, Ipp-mahadewi@undiksha.ac.id ${ }^{2}$, ngrjapa@undiksha.ac.id ${ }^{3}$
}

\begin{abstract}
Abstrak
Penelitian ini dilakukan berdasarkan beberapa masalah sebagai berikut. 1) Hasil belajar IPA siswa masih rendah. 2) Siswa masih suka bermain dalam pelajaran. 3) Guru lebih sering menggunakan metode yang biasa digunakan di sekolah. 4) Guru jarang menggunakan media pembelajaran. Penelitian ini bertujuan untuk mengetahui pengaruh model Teams Games Tournament berbantuan media questions box terhadap hasil belajar siswa kelas V di MIN 2 Buleleng kecamatan Buleleng tahun pelajaran 2017/2018 dalam mata pelajaran IImu Pengetahuan Alam. Populasi penelitian ini adalah kelas V di MIN 2 Buleleng Kecamatan Buleleng tahun pelajaran 2017/2018 yang berjumlah 93 orang. Sampel penelitian ini adalah kelas VB di MIN 2 Buleleng yang berjumlah 32 orang dan kelas VA di MIN 2 Buleleng yang berjumlah 30 orang. Data dikumpulkan dengan tes berbentuk pilihan ganda dengan jumlah soal sebanyak 30 butir. Data yang dikumpulkan dianalisis menggunakan analisis statistik deskriptif dan statistik inferensial (uji-t). Berdasarkan hasil analisis, diperoleh thit $>$ ttab. Hal ini berarti diinterpretasikan bahwa terdapat pengaruh model pembelajaran Team Games Tournament (TGT) bermediakan questions box terhadap hasil belajar IPA siswa kelas $V$ terhadap hasil belajar IPA siswa kelas V di MIN 2 Buleleng Kecamatan Buleleng Tahun Pelajaran 2017/2018.
\end{abstract}

Kata kunci: hasil belajar, pelajaran IPA, TGT.

\begin{abstract}
This study was conducted based on several problems as follows. 1) Students' science learning achievements were still low. 2) Students still loved to play in lessons and they didn't pay attention to the learning process. 3) The teacher tended to use the classical learning method in the school. 4) Teachers rarely use instructional media. This study aims to determine the effect of Teams Games Tournament model with the assistance of questions box towards the learning achievement of 5th grade students in MIN 2 Buleleng Buleleng sub-district in the academic year 2017/2018 in Natural Sciences subject. The population of this study is 5th garde in MIN 2 Singaraja Buleleng SubDistrict in academic year 2017/2018 in which the total number of students are 93 . The sample of this research is the 5th grade B class at MIN 2 Buleleng which amounted to 32 students and 5th grade A class in MIN 2 Buleleng which amounted to 30 students. Data were collected by multiple choice test with 30 items of questionnaire. The data collected were analyzed using descriptive and inferential statistical analysis (t-test). Based on the results of analysis, obtained thit> ttab. This means that there is effect learning model of Team Games Tournament (TGT) in form of questions box on the 5th grade students science learning achievement in MIN 2 Buleleng Buleleng sub-district in the academic year 2017/2018.
\end{abstract}

Keywords : learning achievement, natural science subject, TGT. 


\section{Pendahuluan}

Pendidikan menjadi prioritas setiap orang karena dengan adanya pendidikan harapan sebuah negara dapat terwujud, seorang anak dapat mewujudkan cita-citanya dan mampu menjadi pribadi yang baik. Pendidikan merupakan " usaha sadar, membentuk manusia yang paripurna, memberikan bekal untuk manusia yang akan digunakan dalam beraktifitas seharihari, dan pesan moral yang baik bagi pengembangan hidup dan kehidupannya di masa kini dan masa yang akan datang" (Sutirna dan Asep, 2015:25). Namun saat ini masih saja pendidikan di Indonesia belum bersih dari permasalahan, sehingga pemerintah tetap berpikir untuk memperbaiki permasalahan tersebut. Salah satunya adalah kualitas pendidikan yang belum mencapai taraf yang baik, yakni masih terdapat beberapa siswa yang mengalami permasalahan dalam pembelajaran sehingga hasil belajar siswa masih rendah.

Banyak faktor yang menyebabkan hal tersebut terjadi yaitu, kualitas guru yang masih perlu ditingkatkan, karena guru merupakan salah satu komponen penting dan sekaligus penanggung jawab dalam mewujudkan pendidikan yang berkualitas di sekolah. Guru dituntut untuk menjadi guru yang profesional dalam hal merancang, melaksanakan, dan mengevaluasi pembelajaran. "Guru harus melaksanakan pembelajaran yang tepat dan benar dengan menggunakan berbagai startegi, pendekatan, metode dan media yang sesuai dengan karakteristik perkembangan siswa, lingkungan siswa dan materi pembelajaran."(Sudarmi, 2014).

Selain guru harus menjadi guru yang professional, pemanfaatan media juga sangat penting dan sangat membantu guru dalam menjelaskan materi ajar sehingga siswa lebih mudah dalam memahami materi pembelajaran. Karena dalam pelaksanaan pendidikan baik pendidikan formal atau non formal harus menyediakan sarana dan prasarana yang memenuhi keperluan pendidikan. Sarana dan prasarana yang baik dapat menunjang keberhasilan belajar siswa salah satunya ialah penggunaan media pembelajaran. "Media peranan yang sangat penting, yaitu suatu sarana atau perangkat yang berfungsi sebagai perantara atau saluran dalam suatu proses komunikasi anatara komunikator dan komunikah." (Asyhar, 2012:5). Hal yang lainnya adalah faktor lingkungan siswa yang dapat mempengaruhi siswa dalam bersemangat untuk belajar dan tetap fokus saat pembelajaran. Salah satunya adalah faktor teman yang apabila siswa memiliki teman yang malas maka siswa tersebut akan ikut malas tapi jika siswa lebih banyak dipengaruhi oleh lingkungan yang baik maka teman yang malas itu tidak akan mempengaruhinya untuk menjadi pemalas.

Selain itu pendidikan juga membutuhkan adanya kurikulum, karena kurikulum merupakan aspek yang sangat penting untuk keberhasilan pelaksanaan pendidikan. Saat ini kurikulum di Indonesia telah mengalami perubahan, namun pada dasarnya kurikulum dibuat untuk kemaslahatan pendidikan di Indonesia. Kurikulum terbaru yang digunakan di Indonesia adalah kurikulum 2013, yang diterapkan di beberapa sekolah dasar di Indonesia. Menurut permendikbud 67 tahun 2013, kurikulum 2013 bertujuan untuk mempersiapkan manusia Indonesia agar memiliki kemampuan hidup sebagai pribadi dan warga negara yang beriman, produktif, kreatif, inovatif, dan efektif serta mampu berkontribusi pada kehidupan bermasyarakat, berbangsa, bernegara, dan perdaban dunia. Kurikulum 2013 tidak menjadikan siswa sebagai objek namun sebaliknya siswa dijadikan subjek belajar yang secara aktif ikut dalam pembelajaran dan mengembangkan tema yang ada. Untuk itu agar mutu pendidikan di Indonesia dapat meningkat dan tujuan pendidikan tercapai, maka dibutuhkan upaya dan strategi yang tepat sehingga dapat menghasilkan peningkatan kompetensi pengetahuan siswa khususnya dalam pelajaran IPA.

Berdasarkan observasi pada tanggal 16 Desember 2017 di SD MIN (Madrasah Ibtidaiyah Negeri) 2 Buleleng Kecamatan Buleleng diperoleh informasi tentang beberapa masalah yang dihadapi oleh siswa dalam pelaksanaan pembelajaran IPA di SD MIN (Madrasah Ibtidaiyah Negeri) 2 Buleleng, yaitu (1) masih terdapat hasil belajar atau nilai siswa yang rendah, (2) masih ada siswa yang bermain dan tidak menyimak penjelasan guru yang berdampak pada hasil belajarnya, (3) guru biasanya lebih sering menggunakan metode yang biasanya digunakan di sekolah yaitu metode ceramah dan diskusi, (4) meskipun terdapat media 
pembelajaran salah satunya LCD, namun guru tidak menggunakannya setiap saat dan guru lebih sering menggunakan media berupa papan tulis dan berpedoman pada buku ajar, (5) masih terdapat nilai siswa dibawah KKM.

Berdasarkan hasil wawancara di SD MIN (Madrasah Ibtidaiyah Negeri) 2 Buleleng Kecamatan Buleleng bahwa dalam proses pembelajaran IPA guru masih mengalami kendala dengan beberapa siswa yang sulit diatur, meskipun tidak banyak namun hal tersebut menganggu siswa lain untuk fokus dalam belajar. beberapa guru juga mengalami kendala saat penerapan kurikulum 2013, sehingga guru harus berusaha penuh untuk menguasainya sebelum menerapkannya di kelas. Guru juga jarang menerapkan model inovatif di kelas, bahkan lebih sering hanya menerapkan metode saja. Hal itu tentu membuat siswa menjadi jenuh karena penyajiannya bersifat monoton yang pada akhirnya akan berpengaruh pada hasil belajar siswa sehingga kualitas pembelajaran menjadi rendah. Rendahnya hasil belajar IPA siswa kelas V di MIN (Madrasah Ibtidaiyah Negeri) 2 Buleleng dapat dilihat dari nilai rata-rata Ulangan Akhir Semester yang masih rendah dan masih ada yang berada dibawah KKM (Kriteria Ketuntasan Minimal). Hal tersebut menunjukkan bahwa siswa kurang memahami materi pembelajaran.

Melihat permasalahan tersebut maka perlu diterapkan pembelajaran yang inovatif dan menarik bagi siswa sehingga dapat membuat pembelajaran lebih bermakna dan membuat siswa lebih mudah dalam memahami pembelajaran. Alternatif yang dapat dilakukan adalah menggunakan model pembelajaran Team Games Tournament (TGT). Adapun alasan memilih model TGT, karena kelebihan model TGT yaitu mampu meningkatkan keaktifan siswa di kelas, membuat suasana kelas lebih menyenangkan dengan adanya permainan yang sesuai dengan karakter siswa sekolah dasar yaitu senang bermain. Selain itu penerapan model TGT dalam pembelajaran dapat meningkatkan rasa percaya diri, kerjasama, tanggung jawab dan persaingan sehat antara teman di kelas, pemahaman yang lebih mendalam terhadap pokok bahasan, meningkatkan kebaikan budi pekerti, kepekaan, toleransi antara siswa dengan siswa dan antara siswa dengan guru. TGT juga membuat siswa yang memiliki kognitif rendah bersaing dengan siswa yang memiliki kognitif lebih tinggi, dengan adanya persaingan tersebut maka hasil belajar siswa yang memiliki kognitif rendah akan meningkat.

Berdasarkan hal tersebut maka model pembelajaran TGT sangat dibutuhkan dan cocok untuk diterapkan dalam membantu menyelesaikan permasalahan yang ada. Pelaksanaan model pembelajaran ini akan lebih bermakna apabila proses pembelajaran didukung dengan media pembelajaran, salah satunya adalah media Questions Box. Media Questions Box adalah "media sederhana yang dibuat berbentuk kotak yang di dalamnya berisi sejumlah pertanyaan yang akan di ambil tiap-tiap anggota kelompok secara acak." (Purwantini, 2013). Media ini membantu pelaksanaan pembelajaran kooperatif tipe TGT karena dalam model pembelajaran TGT siswa akan melakukan games dan pada kegiatan atau tahapan tersebut, siswa akan menjawab pertanyaan yang nantinya pertanyaan tersebut di ambil dalam media questions box.

Adapun tujuan yang ingin dicapai dalam penelitian ini yaitu agar dapat mengetahui pengaruh model pembelajaran Team Games Tournament (TGT) bermediakan Questions Box terhadap hasil belajar IPA kelas V SD di MIN (Madrasah Ibtidaiyah Negeri) 2 Buleleng Kecamatan Buleleng Tahun Pelajaran 2017/2018.

\section{Metode}

Tempat pelaksanaan penelitian ini adalah kelas V SD di MIN 2 Buleleng Kecamatan Buleleng. Adapun waktu penelitian ini yaitu pada rentang waktu Semester Genap Tahun Pelajaran 2017/2018. Penelitian ini termasuk dalam bentuk quasi eksperimental (eksperimen semu), yaitu jenis penelitian yang mempunyai kelompok kontrol tetapi tidak dapat berfungsi "Sepenuhnya untuk mengontrol variabel-variabel luar yang mempengaruhi pelaksanaan eksperimen" (Sugiyono, 2011:77).

Desain penelitian eksperimen yang akan digunakan dalam penelitian ini yaitu non equivalent post-test only control group design. maksudnya adalah ada dua kelompok yang dipilih secara random, kelompok pertama diberi perlakuan yakni diterapkan model 
pembelajaran kooperatif tipe TGT dan kelompok kedua tidak diberi perlakuan yakni diterapkan model konvensional. Kelompok pertama diberikan perlakuan oleh peneliti kemudian dilakukan pengukuran, sedangkan kelompok kedua yang digunakan sebagai kelompok pengontrol tidak mendapat perlakuan atau diterapkan konvensional tapi hanya dilakukan pengujian saja.

Desain penelitian eksperimen yang akan digunakan dalam penelitian ini yaitu non equivalent post-test only control group design. maksudnya adalah ada dua kelompok yang dipilih secara random, kelompok pertama diberi perlakuan yakni diterapkan model pembelajaran kooperatif tipe TGT dan kelompok kedua tidak diberi perlakuan yakni diterapkan model konvensional. Kelompok pertama diberikan perlakuan oleh peneliti kemudian dilakukan pengukuran, sedangkan kelompok kedua yang digunakan sebagai kelompok pengontrol tidak mendapat perlakuan atau diterapkan konvensional tapi hanya dilakukan pengujian saja.

Teknik sampling yang akan digunakan dalam penelitian ini adalah teknik random sampling yang di random adalah kelas. Teknik random sampling dilakukan dengan sistem undian. Pengundian sampel ini dilakukan pada semua kelas dan setiap kelas mendapatkan kesempatan yang sama untuk dijadikan sebagai kelas eksperimen dan kelas kontrol.

Sebelum dilakukannya pemilihan sampel, terlebih dahulu dilakukan uji kesetaraan untuk mengetahui kemampuan siswa kelas V di MIN (Madrasah Ibtidaiyah Negeri) 2 Buleleng sudah setara atau belum. Selain itu, uji kesetaraan ini dimaksudkan untuk menyakini bahwa kelas yang akan dijadikan sampel adalah kelas yang setara. Uji kesetaraan pada penelitian ini dilakukan dengan menganalisis nilai Ulangan Akhir Semester (UAS) mata pelajaran IPA siswa kelas V MIN (Madrasah Ibtidaiyah Negeri) 2 Buleleng di Kecamatan Buleleng Kabupaten Buleleng pada semester ganjil tahun pelajaran 2017/2018.

Berdasarkan hasil analisis varians pada taraf signifikansi $5 \%$ diperoleh nilai Fhitung sebesar 0,03 sedangkan nilai Ftabel pada dbantar 2 dan dbdalam 90 adalah 3,44. Dengan demikian terlihat bahwa nilai Fhitung < Ftabel $(0,03<3,44)$, sehingga $\mathrm{HO}$ diterima dan $\mathrm{H} 1$ ditolak. Jadi, tidak terdapat perbedaan hasil UAS semester ganjil tahun pelajaran 2017/2018 mata pelajaran IPA pada siswa kelas V di MIN (Madrasah Ibtidaiyah Negeri) 2 Buleleng Kecamatan Buleleng Kabupaten Buleleng. Dengan kata lain, bahwa kemampuan siswa kelas $\mathrm{V}$ di MIN (Madrasah Ibtidaiyah Negeri) 2 Buleleng Kecamatan Buleleng Kabupaten Buleleng adalah homogen atau setara.

Kelas yang dirandom merupakan kelas dalam jenjang yang sama. Kelas-kelas tersebut adalah kelas V di MIN (Madrasah Ibtidaiyah Negeri) 2 Buleleng Kecamatan Buleleng. Dari 3 kelas yang ada yang ada di MIN (Madrasah Ibtidaiyah Negeri) 2 Buleleng Kecamatan Buleleng yang menggunakan kurikulum 2013, dilakukan pengundian untuk menentukan kelas eksperimen dan kelas kontrol. Berdasarkan hasil pengundian menyatakan yang menjadi sampel penelitian adalah siswa kelas VB sebagai kelas eksperimen dan siswa kelas VA sebagai kelas kontrol.

Metode pengumpulan data dalam penelitian ini adalah metode tes. Instrumen yang digunakan untuk memperoleh data tentang hasil belajar IPA dalam penelitian ini berupa tes objektif (pilihan ganda) dengan satu jawaban benar yang berjumlah 40 butir soal. Sebanyak 40 butir soal tersebut diberikan kepada siswa kelas $\mathrm{V}$ dengan tujuan validasi butir tes. Post-test yang diberikan kepada siswa adalah tes objektif pilihan ganda yang berjumlah 30 butir yang merupakan soal hasil dari validitas butir tes soal. Pengujian instrumen penelitian dilakukan untuk mendapat gambaran secara empirik mengenai layak tidaknya instrumen tersebut digunakan sebagai instrumen penelitian. Syarat instrumen penelitian yang diuji dalam penelitian ini adalah validitas tes, reliabilitas tes, taraf kesukaran tes, dan daya beda tes.

Pengujian instrumen yang pertama adalah uji validitas dilakukan dengan menggunakan rumus Gregory yakni untuk menentukan koefisien validitas isi, hasil penelitian dari kedua pakar terhadap tes hasil belajar IPA. Validitas isi tes hasil belajar dalam mata pelajaran IPA termasuk dalam kriteria sangat tinggi yakni seluruh soal relevan. Selanjutnya soal sebanyak 40 butir diuji cobakan kepada siswa kelas VI dengan total siswa sebanyak 92 orang. Kemudian hasil uji coba dianalisis menggunakan korelasi point biserial, hasil analisis diperoleh 35 butir soal yang valid dari 40 butir soal yang diuji cobakan. 
Pengujian instrumen selanjutnya yaitu uji reliabilitas dengan menggunakan rumus Kuder Richardson 20 (KR-20) dan diperoleh koefisien reliabilitas sebesar 0,879. Hal ini berarti, tes yang diuji termasuk ke dalam kriteria reliabilitas sangat tinggi.

Selanjutnya dilakukan pengujian tingkat kesukaran tes, diperoleh 40 butir soal dengan kategori sedang. Uji daya beda tes diperoleh hasil yaitu 19 dengan kategori sangat baik, 11 dengan kategori baik, 5 cukup baik dan 5 sangat kurang baik.

Metode analisis data dalam penelitian ini menggunakan metode analisis statistik deskriptif, statistik inferensial dan uji-t. Analisis deskriptif menampilkan rata-rata, standar deviasi, median, nilai minimum, nilai maksimum,jangkauan, dan jumlah data dari setiap variabel yang diteliti. Sedangkan statistik inferensial terdiri dari uji normalitas dan homogenitas sedangkan Uji-t digunakan untuk menguji hipotesis penelitian adapun rumus uji-yang digunakan polled varianadalah uji normalitas sebaran data dengan chi-kuadrat dan uji homogenitas varians dengan uji F.

\section{Hasil dan Pembahasan}

Data dalam penelitian ini adalah skor hasil belajar IPA siswa kelas $V$ sebagai akibat dari pengaruh model pembelajaran TGT pada kelompok eksperimen dan model pembelajaran konvensional pada kelompok kelas kontrol. Analisis selengkapnya disajikan seperti pada lampiran. Selanjutnya disajikan rekapitulasi tentang hasil belajar IPA Kelompok kelas eksperimen dan kontrol pada tabel 1.

Tabel 1. Rekapitulasi Hasil Belajar IPA

\begin{tabular}{ccc}
\hline Data Statistik & Kelompok Eksperimen & Kelompok Kontrol \\
\hline Mean & 22,71 & 18,20 \\
Median & 22,85 & 18,09 \\
Modus & 23 & 17,73 \\
Varians & 13,56 & 16,72 \\
Standar Deviasi & 3,68 & 4,68 \\
Skor Minimal & 13 & 11 \\
Skor Maksimal & 29 & 25 \\
\hline
\end{tabular}

Nilai mean, median dan modus dapat disajikan dalam bentuk kurva polygon seperti gambar 1. Tujuannya untuk menafsirkan sebaran data hasil belajar IPA pada kelompok eksperimen. Hubungan antara mean, median, dan modus dapat digunakan untuk menentukan kemiringan kurva polygon distribusi frekuensi. 


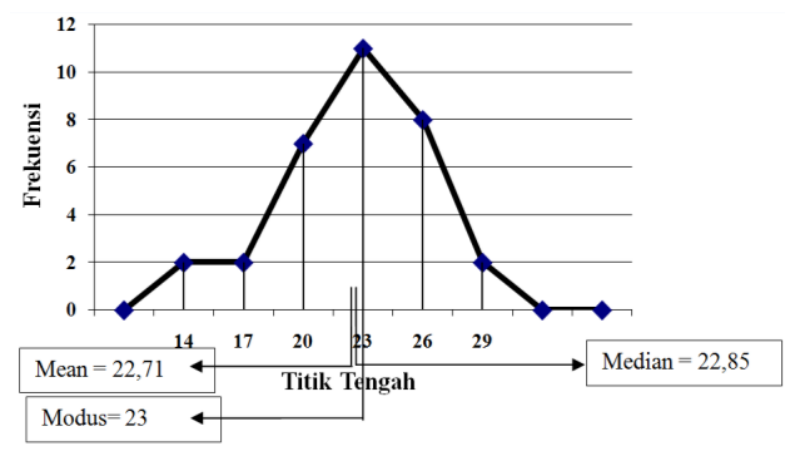

Gambar 1. Polygon Data Post-Test IPA Kelompok Eksperimen

Gambar 1 menunjukkan bahwa modus lebih besar dari median dan median lebih besar dar mean $\mathrm{Mo}>\mathrm{Md}>\mathrm{M}(22,85>23>22,71)$. Dengan demikian, polygon di atas menggambarkan kurva juling negatif yang berarti sebagian besar skor cenderung tinggi. Namun jika nilai ratarata dikonversikan ke dalam kategori skala lima berada dalam kategori sangat tinggi. Distribusi frekuensi tentang hasil belajar IPA pada kelas kontrol dasajikan pada gambar 2 .

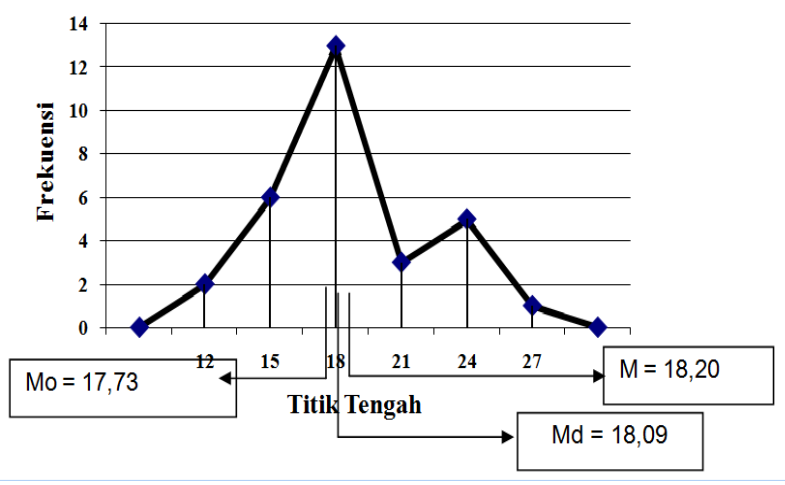

Gambar 2. Polygon Data Post-Test IPA Kelompok Kontrol

Gambar 2 menunjukkan bahwa mean lebih besar dari median dan modus lebih besar dari modus $M>M d>M o(18,20>18,09>17,73)$. Dengan demikian, polygon di atas menggambarkan kurva juling positif yang berarti sebagian besar skor cenderung rendah. Jika nilai rata-rata dikonversikan ke dalam kategori skala lima berada dalam kategori sedang.

Uji normalitas dilakukan untuk menyelidiki suatu distribusi empirik mengikuti ciri-ciri distribusi normal atau untuk menyelidiki fo (frekuensi observasi) dari gejala yang diselidiki tidak menyimpang secara signifikan dari fh (frekuensi harapan) dalam distribusi normal. Uji normalitas data dilakukan terhadap data post-test siswa pada mata pelajaran IPA kelompok eksperimen dan kelompok kontrol.

Berdasarkan hasil perhitungan dengan menggunakan rumus chi-kuadrat, diperoleh $\chi^{2}{ }_{h i t}$ hasil post-test kelompok eksperimen adalah 3,51 dan $\chi_{\text {tab }}^{2}$ dengan taraf signifikansi $5 \%$ dan dk $=5$ adalah 11,07 . Hal ini berarti, $\chi^{2}{ }_{\text {hit }}$ hasil post-test kelompok eksperimen lebih kecil dari $\chi_{\text {tab }}^{2}\left(\chi_{h i t}^{2}<\chi_{t a b}^{2}\right)$, sehingga data hasil post-test kelompok eksperimen berdistribusi normal. Sedangkan, $\chi_{h i t}^{2}$ hasil post-test kelompok kontrol adalah 5,24 dan $\chi_{\text {tab }}^{2}$ dengan taraf signifikansi $5 \%$ dan $\mathrm{dk}=5$ adalah 11,07 . Hal ini berarti, $\chi^{2}$ hit hasil post-test kelompok kontrol lebih kecil dari $\chi_{t a b}^{2}\left(\chi_{h i t}^{2}<\chi_{t a b}^{2}\right)$, sehingga data hasil post-test kelompok kontrol berdistribusi normal. 
Uji homogenitas dilakukan terhadap varians pasangan antara kelompok eksperimen dan kelompok kontrol. Uji yang digunakan adalah uji $F$ dengan kriteria data homogen jika $F_{\text {hit }}<F_{\text {tab. }}$ $F_{\text {hit. }}$ Berdasarkan hasil perhitungan uji homegenitas hasil post-test kelompok eksperimen dan kelompok kontrol adalah 1,23. Sedangkan $F_{\text {tab }}$ dengan dbpembilang $=32$, dbpenyebut $=30$, dan taraf signifikansi $5 \%$ adalah 1,78. Hal ini berarti, varians data hasil post-test kelompok eksperimen dan kelompok kontrol adalah homogen.

Berdasarkan uji prasyarat analisis data, diperoleh bahwa data hasil post-test kelompok eksperimen dan kelompok kontrol adalah normal dan homogen. Setelah diperoleh hasil dari uji prasyarat analisis data, dilanjutkan dengan pengujian hipotesis penelitian $\left(\mathrm{H}_{1}\right)$ dan hipotesis nol $\left(\mathrm{H}_{0}\right)$. Pengujian hipotesis tersebut dilakukan dengan menggunakan uji-t sampel independent (tidak berkorelasi) dengan rumus polled varians dengan kriteria $H_{0}$ tolak jika $t_{\text {hit }}>t_{\text {tab }}$ dan $H_{0}$ terima jika $t_{\text {hit }}<t_{\text {tab }}$.

Berdasarkan hasil perhitungan uji-t, diperoleh $t_{\text {hit }}$ sebesar 4,75 . Sedangkan $t_{\text {tab }}$ dengan $d k$ $=32+30-2=60$ dan taraf signifikansi $5 \%$ adalah $3,15 \mathrm{Hal}$ ini berarti, $t_{\text {hit }}$ lebih besar dari $t_{\text {tab }}$ ( $t_{\text {hit }}>$ $\left.t_{\text {tab }}\right)$, sehingga $\mathrm{H}_{0}$ ditolak dan $\mathrm{H}_{1}$ diterima. Dengan demikian, dapat diinterpretasikan bahwa terdapat pengaruh yang signifikan model pembelajaran TGT (Team Games Tournament) bermediakan questions box terhadap hasil belajar IPA siswa kelas V SD di MIN 2 Buleleng Kecamatan Buleleng Tahun Pelajaran 2017/2018.

Berdasarkan analisis data yang telah dilakukan diketahui hasil penelitian ini menunjukkan bahwa terdapat pengaruh yang signifikan model pembelajaran TGT bermediakan questions box terhadap hasil belajar IPA siswa kelas V SD di MIN 2 Buleleng Kecamatan Buleleng Tahun Pelajaran 2017/2018, yaitu hasil belajar kelas eksperimen lebih tinggi dibandingkan hasil belajar di kelas kontrol. Hal tersebut didukung oleh beberapa temuan pada penelitian ini, yaitu sebagai berikut.

Pertama menumbuhkan motivasi siswa dalam belajar. Hal ini dilihat pada saat guru menyajikan permainan yang membuat siswa lebih termotivasi untuk dapat menang. Setiap kelompok tampak semangat untuk mendapat skor yang paling tinggi dalam permainan. Guru hanya sedikit saja memberi dorongan dikarenakan siswa sudah termotivasi dengan sendirinya. Motivasi adalah aspek yang sangat penting untuk membelajarkan siswa. Dengan adanya motivasi/dorongan dapat memungkinkan siswa untuk melakukan sesuatu. Hal ini sesuai dengan pendapat Suwatra,dkk $(2015 ; 104)$ "perbuatan belajar akan terjadi apabila anak memiliki motivasi yang baik."

Kedua, pembelajaran ini melatih siswa untuk berpikir kreatif dan aktif dalam pembelajaran. Hal ini ditemui pada saat kegiatan diskusi kelompok dan saat tanya jawab. Dalam diskusi kelompok dapat terjalin kerjasama antar siswa sehingga siswa terlibat aktif dalam pembelajaran dan memahami materi yang sedang dipelajari. Selain itu, secara tidak langsung siswa belajar untuk saling memahami dan menghormati pendapat orang lain. Dengan demikian, kerjasama dalam diskusi kelompok dapat menjadikan siswa lebih memahami materi dan meningkatkan pemahaman konsep. Kusumaningrum (2014) menyatakan "model pembelajaran kooperatif tipe Teams Games Tournament (TGT) dapat meningkatkan interaksi dan kerjasama siswa dalam kelompok belajar, interaksi dan kerjasama akan terlihat ketika siswa mengerjakan dan membahas tugas yang diberikan oleh guru."

Ketiga, dalam model pembelajaran TGT peran guru dalam pembelajaran hanya sebagai fasilitator dan motivator. Peran guru sebagai fasilitator terlihat pada saat menjelaskan materi dan memberikan tanggung jawab kepada siswa untuk membantu siswa yang lainnya memahami materi pelajaran. Sedangkan peran guru sebagai motivator tercermin pada proses pembelajaran guru selalu memberikan motivasi bagi siswa untuk dapat memahami materi pelajaran dan selanjutnya siswa dimotivasi untuk dapat menang dalam turnamen selain itu siswa juga diarahkan dalam diskusi untuk saling membantu teman kelompoknya dan menyelesaikan tugas yang diberikan oleh guru. Hal ini sependapat dengan Saptayanti (2016) "Peran guru dalam pembelajaran dengan model pembelajaran kooperatif tipe teams games tournament berbantuan, sebagai fasilitator dan moderator yang memberikan tanggung jawab kepada siswa untuk meningkatkan hasil belajar" 
Selain itu model TGT ini memiliki tahapan yang membedakan dengan model pembelajaran konvensional yaitu pada tahap pertama, guru menyampaikan materi ajar kepada siswa, namun sebelumnya guru seperti biasa menyampaikan tujuan dan apersepsi. Tujuan dari guru menyampaikan materi ajar ini adalah agar siswa dapat terlatih untuk menyimak dengan baik, dan materi ini dibutuhkan siswa saat siswa berdiskusi dan menjawab soal pada games/tournament.

Tahap kedua, yakni membentuk siswa ke dalam kelompok-kelompok kecil. Guru menempatkan siswa dalam kelompok-kelompok belajar yang memiliki kemampuan dan jenis kelamin yang berbeda. Dalam tahap ini, siswa mendalami materi bersama teman kelompoknya dan lebih khusus untuk mempersiapkan anggota kelompok agar bekerja dengan baik dan optimal pada saat game/turnamen. Guru memberikan tugas kepada setiap kelompok, pada tahap ini siswa mulai tampak berdiskusi dan saling membantu antar teman kelompoknya. Namun guru juga membimbing dan tetap memotivasi siswa untuk menyelesaikan tugas yang diberikan oleh guru. Hal ini sependapat dengan Dewi (2017) yang menyatakan bahwa "dalam proses pembelajaran guru memposisikan diri sebagai motivator dan fasilitator aktivitas siswa."

Tahap ketiga yaitu games/tournament, pada tahap ini siswa melakukan games/tournament dengan menggunakan media questions box yakni media tersebut digunakan oleh siswa untuk mendapatkan soal-soal yang harus dijawab dalam games/tournament. Tujuan dari games/tournament untuk mengetahui pengetahuan siswa dalam pembelajaran IPA. hal ini sesuai dengan pendapat Taniredja., dkk (2012) tentang kelebihan model pembelajaran TGT yaitu "(1) dalam kelas kooperatif siswa memiliki kebebasan untuk berinteraksi dan menggunaan pendapatnya; (2) rasa percaya diri siswa menjadi lebih tinggi."

Tahap keempat yaitu memberikan penghargaan, Guru mengumumkan kelompok yang memperoleh skor/nilai tertinggi kemudian memberikan penghargaan kepada kelompok pemenang salah satunya dengan memberikan pujian kepada kelompok yang menang. Hal ini sesuai dengan pendapat Suwatra,dkk (2015:133) menyatakan, "pemberian pujian merupakan reinforcement yang positif dan sekaligus motivasi yang baik."

Berbeda halnya dengan kelas yang menggunakan model pembelajaran konvensional. Pembelajaran konvensional, guru cenderung lebih aktif sebagai sumber informasi bagi siswa dan siswa cenderung pasif dalam mengikuti pembelajaran. Kepasifan siswa menjadikan komunikasi yang terjalin hanya komunikasi satu arah yaitu antara guru dengan siswa. Guru sesekali meminta siswa yang memiliki kognitif yang lebih tinggi di kelas untuk mengemukakan pendapat. Meskipun pada kelas kontrol diberikan metode diskusi namun siswa yang memiliki kognitif rendah akan tetap pasif dan guru tidak memberikan tanggung jawab kepada setiap anggota kelompok untuk saling membantu dan bekerjasama agar seluruh anggota kelompok memahami materi pelajaran.

Perbedaan lainnya yakni pada kelas konvensional siswa yang kognitif lebih rendah tidak termotivasi untuk menunjukkan dirinya dan lebih memilih untuk diam dan mendengarkan. Berbeda dengan kelas eksperimen, siswa yang memiliki kognitif rendah ditantang sehingga termotivasi untuk dapat lebih baik karena siswa harus menang dalam permainan.

Perbedaan cara pembelajaran yang digunakan oleh guru antara kelas kelas eksperimen dengan model pembelajaran teams games tournament (TGT) bermediakan questions box dan kelas kontrol dengan model pembelajaran konvensional tentunya memberikan dampak yang berbeda terhadap hasil belajar IPA siswa. Penggunaan model pembelajaran teams games tournament (TGT) bermediakan questions box dalam pembelajarannya yang disertai dengan tournament akademik akan mampu melatih siswa untuk berani berbicara dan mengemukakan pendapat yang bertujuan membiasakan siswa serta memudahkan siswa untuk mengingat pelajaran yang telah diberikan.

Perbedaan hasil belajar dari kedua kelas tersebut dibuktikan melalui rata-rata hasil belajar kedua kelas tersebut yaitu rata-rata $(\bar{X})$ hitung kelompok eksperimen yakni kelas yang diterapkan menggunakan model TGT adalah 22,71 dan $\bar{X}$ kelompok kontrol yakni kelas yang 
diterapkan menggunakan model konvemsional adalah 18,20. Dengan demikian, dapat disimpulkan bahwa model pembelajaran TGT bermediakan questions box berpengaruh positif terhadap hasil belajar IPA siswa kelas V SD di MIN 2 Buleleng Kecamatan Buleleng Tahun Pelajaran 2017/2018.

Temuan hasil penelitian di atas sesuai dengan temuan sebelumnya. Temuan penelitian tersebut antara lain sebagai berikut. Muldayanti (2013) Hasil penelitiannya menyatakan bahwa penerapan metode STAD dan TGT, keingintahuan tinggi atau rendah, dan minat belajar tinggi dan rendah mempengaruhi prestasi dan memberikan interaksi secara bersamaan dalam meningkatkan prestasi belajar.

Wati (2015) pada hasil penelitiannya menyatakan bahwa berdasarkan hasil analisis data dan pembahasan penelitian, dapat disimpulkan bahwa terdapat pengaruh yang signifikan pada model pembelajaran kooperatif tipe TGT (Teams Games Tournament) terhadap hasil belajar siswa kelas $\mathrm{V}$ pada tema ekosistem. Hal ini ditunjukkan oleh hasil uji-t yang diperoleh yaitu t-hitung $(-5,376)>$ t-tabel $(2.005)$ dengan taraf signifikan $5 \%$.

\section{Simpulan dan Saran}

Berdasarkan rumusan masalah dan hasil penelitian, maka simpulan dalam penelitian ini adalah terdapat pengaruh model pembelajaran Team Games Tournament (TGT) bermediakan Questions Box terhadap hasil belajar IPA kelas V SD di MIN (Madrasah Ibtidaiyah Negeri) 2 Buleleng Kecamatan Buleleng Tahun Pelajaran 2017/2018.

Hal ini ditunjukkan pada hasil hipotesis uji-t yang diketahui bahwa thitung $=4,75>$ ttabel $=3,15$ berarti $\mathrm{HO}$ ditolak dan $\mathrm{H} 1$ diterima. Hal ini berarti terdapat pengaruh model pembelajaran Team Games Tournament (TGT) bermediakan Questions Box terhadap hasil belajar IPA kelas V SD di MIN (Madrasah Ibtidaiyah Negeri) 2 Buleleng Kecamatan Buleleng Tahun Pelajaran 2017/2018.

Saran yang dapat disampaikan berdasarkan penelitian yang telah dilakukan adalah sebagai berikut. Saran yang dapat diberikan kepada siswa SD yaitu agar lebih fokus dan aktif dalam proses pembelajaran untuk dapat mengembangkan pengetahuannya serta melalui penerapan model pembelajaran ini siswa bisa menumbuhkan motivasi belajarnya.

Guru SD hendaknya lebih mengkreasikan pembelajaran dengan cara menerapkan model-model pembelajaran yang inovatif, salah satunya adalah model pembelajaran TGT dan didukung media pembelajaran yang relevan untuk dapat meningkatkan hasil belajar siswa khususnya pada mata pelajaran IPA, sebab telah terbukti pada penelitian ini bahwa terdapat perbedaan hasil belajar siswa yang signifikan antara siswa yang dibelajarkan dengan model pembelajaran TGT dan siswa yang dibelajarkan dengan model pembelajaran konvensional.

Kepala sekolah hendaknya mampu mengambil tindakan dalam upaya meningkatkan kualitas pembelajaran melalui pengarahan kepada guru-guru sebagai alternatif pilihan menggunakan model pembelajaran inovatif, salah satunya model pembelajaran TGT. Peneliti yang berminat untuk mengadakan penelitian lebih lanjut tentang model pembelajaran TGT dalam bidang IPA maupun bidang ilmu lainnya yang sesuai agar memperhatikan kendalakendala yang dialami dalam penelitian ini sebagai bahan pertimbangan untuk perbaikan dan penyempurnaan penelitian yang akan dilaksanakan..

\section{Daftar Pustaka}

Dewi, I. A. Kd. Novia Puspita. 2017. "PENGARUH MODEL PEMBELAJARAN KOOPERATIF TIPE TGT TERHADAP HASIL BELAJAR PKN SISWA KELAS V SD”. e-Journal Mimbar PGSD Universitas Pendidikan Ganesha Jurusan PGSD, Vol5, No 2.

Kusumaningrum, Putu Citra Arni. 2014. "Pengaruh Model Pembelajaran Kooperatif Tipe Team Games Tournament (TGT) Terhadap Hasil Belajar IPA Pada Siswa Kelas V Gugus XV Kecamatan Buleleng Tahun Ajaran 2013/2014". e-Journal Mimbar PGSD Universitas Pendidikan Ganesha Jurusan PGSD, Vol 2, No 1. 
Muldayanti, N.D., 2013. "PEMBELAJARAN BIOLOGI MODEL STAD DAN TGT DITINJAU DARI MINAT BELAJAR SISWA". Jurnal Pendidikan Ipa Indonesia, Volume 2, Nomor 1 (12-17).

Peraturan Menteri Pendidikan dan Kebudayaan Republik Indonesia 67 tahun 2013 tentang Kerangka Dasar dan Struktur Kurikulum Sekolah Dasar/Madrasah Ibtidaiyah. Jakarta: Depdiknas.

Saptayanti, Gusti Ayu Kadek Emi. 2016. "PENGARUH MODEL PEMBELAJARAN KOOPERATIF TIPE TGT (TEAM GAMES TOURNAMENT) TERHADAP HASIL BELAJAR MATEMATIKA". e-Journal Mimbar PGSD Universitas Pendidikan Ganesha Jurusan PGSD, Vol 4, No 1.

Sudarmi, Yanthi Made. 2014. "PENERAPAN MODEL PEMBELAJARAN KOOPERATIF TIPE TEAM GAMES TOURNAMENT (TGT) UNUTK MENINGKATKAN HASIL BELAJAR PENDIDIKAN KEWARGANEGARAAN". e-Journal Mimbar PGSD Universitas Pendidikan Ganesha Jurusan PGSD, Vol 2, No 1.

Sugiyono. 2011. Metode Penelitian Pendidikan (Pendekatan Kuantitaif, Kualitatif, dan R\&D). Bandung: Alfabeta.

Sutirna dan Asep Samsudin.2015. Landasan Kependidikan Teori dan Praktek.

Suwatra, Ign I Wayan, dkk. 2015. Belajar dan Pembelajaran Sekolah Dasar. Singaraja:Undiksha.

Taniredja, Tukiran, dkk. 2011. Model-Model Pembelajaran Inovatif. Bandung: Alfabeta.

Wati, Ajeng Aprina. 2015. "PENGARUH MODEL PEMBELAJARAN KOOPERATIF TIPE TGT (TEAM GAMES TOURNAMENT) TERHADAP HASIL BELAJAR SISWA KELAS V TEMA 8DI SDN BABATAN I/456 SURABAYA". Jurnal Penelitian Pendidikan Guru Sekolah Dasar Universitas Negeri Surabaya, Volume 03, Nomor 02. 